\title{
The Impact of Money Supply on Inflation Rate in Ghana
}

\author{
Sampson Vivian Esumanba ${ }^{1 *} \quad$ Nantogmah Danaa $^{2} \quad$ Nyaku Efia Akyaa Konadu ${ }^{3}$ \\ 1.Vivian and Associate Consultancy Ltd, P. O. Box KJ 538, Kumasi \\ 2.Department of Banking and Finance. UPSA \\ 3.MBA Student, Banking and Finance
}

\begin{abstract}
The main purpose of the study was to empirically investigate the impact of money supply on inflation rate in Ghana using semi-annual series ranging from December 1990 to June 2017. Specifically, the Autoregressive Distributed Lag (ARDL) approach to cointegration was employed to ascertain the long-run and short-run relationship between the series. The findings from the study revealed that, growth in money supply (GMS) has a positive significant impact on inflation rate (INFR) in the long-run. However, no significant association was found between money supply and inflation in the short-run. Political instability during election year that arises from the manipulation of fiscal policy in order for the incumbent government to increase the likelihood of winning the next election was found to have a negative and significant impact on inflation rate in the short run.
\end{abstract}

Keywords: Money Supply, Inflation, government spending, Ghana

DOI: $10.7176 /$ RJFA/10-16-17

Publication date: August $31^{\text {st }} 2019$

\section{Introduction}

In economics, it is generally accepted that high prices of goods and services is sufficiently enough to weaken the purchasing power of scarce capital of central government, firms, households and individuals (Peterson, Farmer, Lasky \& Weinstein, 2009). In view of its negative effect on individuals, firms, governments, and growth. For decades, inflation targeting has remain a key monetary and fiscal policy objective in both developed and developing countries. (Adu \& Marbuah, 2011; Isakova, 2007). The negative effect of inflation on purchasing power and government policy formulation has made this variable a major focus in economic policy and is mostly seen in the annual budget of most developing countries including Ghana (BOG, 2013; Anwar \&Islam, 2011; Adu \& Marbuah, 2011). Politician have also argued on the volatility in inflation and for several years, it has been an area that the party in opposition normally harmer on to undermine the government in power.

The extent to which inflation affect economic growth varies across country. Most developed countries have found ways to stabilize inflation so that it negative impact on economic growth will be minimize (Taylor, 2014; Anwar \& Islam, 2011). While developed countries have implemented stringent policies and have helped in attaining single digit inflation, developing countries such as Ghana, Sierra Leon, Uganda, and Zimbabwe recorded three-digit inflation (Anwar \& Islam, 2011; Dua\& Gaur, 2009; Loungani \& Swagel, 2001). A study by the Institute of Economic Affairs (IEA), on inflation trends in Ghana revealed that, Ghana for a long period has experience high level of inflation. They argued that, for a period of thirty years (1979 - 2009), "monetization of fiscal deficit" and "cyclical food deficit" are the main driving force of inflation. This suggest that policy to curb inflation in Ghana has been ineffective. During this thirty years' period (1979 to 2009), the rate of inflation was above single digit with annual average of 32 percent. The highest during this range of period was recorded in 1983 with inflation rate as high as 142.4 percent.

Empirical literature on the cause of inflation in Ghana attributed this high rate of inflation from demand pressure coming from monetization of fiscal deficit. Just after Ghana had gain independence, the government set up the Central Bank to conduct monetary policy. Over a long period, the Central Bank has been the sole financier for all government budgets. This act of independent monetary policy by the Central Bank strewed the seed for future high inflation (Kwakye, 2010). In contrast to countries that normally finance it budget through unions, it can be concluded that the high rate of inflation in Ghana cannot be attributed to chance. This is not to say that, about 100 percent of the variance in inflation rate in the country can be explained by the variance in monetary phenomenon. Other studies have also revealed that, the determinants of inflation are numerous and its impact in economic growth varies from country to country (Campillo \& Miron, 1997). After deregulation of the economy through the Economic Recovery Program (ERP) and the Structural Adjustment Program (SAPs), it was also revealed that, cost pressure has a significant impact on inflation. Some of these cost pressures are pressure coming from the high cost of energy and utility prices and also, pressure due to exchange rate depreciation. As a country's inflation becomes rooted, it expectation is also entrenched in wages, exchange rate, interest rate, political business cycle such as election year, and international oil prices. From June 2009, inflation rate of Ghana decreased from 20.7 percent to 8.8 percent in January 2013 . The decline in inflation rate can be attributed to the low volatility in the Cedi to Dollar exchange rate. Furthermore, Kwakye (2010) stated that, the decline in inflation rate during this period was as a result of a reduction in government expenditure which caused a reduction in the quantity of money 
circulating in the economy. A decline in monetary growth implies a reduction in aggregate demand which reduces inflation rate. Though the target of a single digit inflation rate was achieved, it started trending up to a double-digit figure after January 2013.

The fundamental concept of economics suggests that, inflation is dependent on the quantity of excess money circulating in an economy. Economist have general consensus that, a causal relationship exists between monetary inflation and price inflation. However, a common view on the relationship between these variables, the appropriate theoretical mechanism as well as how to precisely measure it have not been envisaged. Also, the relationship keeps changing when a larger complex economic system is taken into consideration. Due to this, there is a great deal of discourse analysis on how to measure the impact of money supply inflation and price inflation, how to quantify the effect of citizenry expectations, the consequence of money supply shocks or financial innovations on inflation, and the extent the velocity of money impacts on the relationship. Though much studies have been done to examine the impact of the various economic variables on inflation, there is little empirical literature on the long-run and short-run relationship as compared to evidence from developed countries. Empirical studies on the predictors of inflation has revealed that, the determinants of inflation are numerous and vary across countries (Campillo \& Miron, 1997). This might be due to the methodology and the range of data used. Finally, most of the study concerning inflation in Ghana relied on and annual data which can superimpose the actual impact of the independent variables on inflation since they are normally multiple averages (Perevalov \& Maier, 2010; Reilly, 2013). Also, most of the study conducted on the impact of macroeconomic indicators on inflation failed to include the impact of political instability such as election year on inflation. This study examines the long-run and shortrun relationship between money supply and inflation rate as well as the impact of political instability (election year) on inflation using current semi-annual data ranging from December 1990 to June 2017.

\section{Literature Review: Theoretical Review}

An investigation of the determinant or the causes of inflation has undoubtedly given rise to one of the most significant macroeconomic discourse analysis in in relation to the field of economics (Totonchi, 2011). There is variation in their hypotheses, due to the series of conventional opinions concerning the suitable measure to regulate inflation coupled with the disparity among developed and developing countries. Totonchi (2011) further argued that, the general causes of inflation in developed countries can be broadly attributed to the quantity of money in circulation while in developing countries; inflation is not fully monetary as growth of money supply. In developing countries, in contrast, inflation is not a purely monetary. Influences associated with fiscal imbalances including higher monetary growth rate as well as exchange rate depreciation resulting from balance of payments predicament control the inflation process in developing countries (Sergent \& Wallace, 1981; Montiel, 1989).

In this section competing and complementary theories of inflation are reviewed. Specifically, the quantity theory of money, monetary theory of inflation, structural theory of inflation, demand pull theory, and supply push theory are fully reviewed and discuss in the next section

\subsubsection{Quantity theory of money}

One of the earliest and most important theoretical suggestion or proposition in modern economic doctrine is the quantity theory of money which is sometimes referred as the transactions approach (Patuti \& Tatulescu, 2013). Generally, the French social philosopher, Jean Bodin is considered the chief originator of the quantity theory of money. The theory date back 16th century when Jean Bodin attributed the increase in the price of goods then raging in Western Europe to the huge quantity of monetary metals (Silver and Gold) which was imported from the mines in South America.By 20th century, the quantity theory of money had undergone received sophisticated refinement, elaboration, and extension by John Locke, Richard Cantillon, and David Hume and integrated into the mainstream of orthodox monetary tradition. It is now the core of the classical monetary analysis and provides the dominant conceptual framework for the understanding and interpretation of financial events. In this present time, the theory continues to flourish in the doctrine of monetarist.

Basically, the quantity theory of money is seen as a hypothesis in relation to the impact of the purchasing power of money on prices of goods and services. The theory suggests that, the changes in the value of money is dependent on the quantity of money in circulation. Milton Friedman who is considered the father of monetarism argued that, domestic inflation is everywhere and it is a monetary phenomenon (Kemal, 2006). He further posits that the changes in overall price level are can only be attributed to the changes in monetary money supply. The basic idea is that, more money circulating in an economy indicate a situation where there are more money chasing fewer goods. This will cause an increase in consumption and an increase in the demand for goods and services which will make prices of goods and services high. Conversely, if their quantity of money in circulation is scanty or scarce, purchasing power rises and the general prices of goods and services falls (Vaish, 2011). Simply put, the quantity theory of money state that, the stock of money or the quantity of money in circulation "M", is the main determinant of the price levels "P" of goods and services. The association between the quantity of money circulating in an economy and the price level is captured in the Fisher equation below:

$$
M V=P Y
$$


Where,

$$
\begin{gathered}
M=\text { Quantity of money in circulation } \\
V=\text { Velocity of circulation of money } \\
P=\text { Price levels } \\
Y=\text { Real National Income }
\end{gathered}
$$

Apart from the general conclusion that, the quantity of money in circulation have impact on price levels of goods and services, the Fisher equation also consist of interrelated postulate that support the brief conclusion. The most vital of these postulates include: the proportionality of the quantity of money in circulation "M" and the price level "P", and the causal role of the quantity of money in circulation in monetary transmission mechanism. According to the proportionality postulate, there is a direct variation in the price level "P" and the change in the quantity of money " $\mathrm{M}$ ". this proposition follows from the assumption that, individuals for the purpose of transaction would hold a fixed quantity of real cash balance " $M / P$ " at the economy's full capacity level of real output. The second important preposition in the quantity theory of money indicate that, there is a unidirectional causality running from quantity of money in circulation " $\mathrm{M}$ " to price level " $\mathrm{P}$ ". This suggest that monetary changes cause changes in price levels. In this causal relationship, money supply is considered as the independent variable while price level is the dependent variable.

\subsubsection{Monetarist theory of inflation}

The monetarist theory of inflation can be attributed to the work of Milton Friedman, who tried to revive the idea that, price level changes with a proportionate change in the quantity of money in stock. Monetary theory of inflation is rooted in the quantity theory of money. It is an improved form of the conventional quantity theory of money. According to the theory, "only money matters", and as such, when it comes to policy to stabilize the economy, monetary policy is more compelling tool than fiscal policy (Khandan \& Hosseini, 2016). Monetarists are of the opinion that, the general level of price results only from an increase in the quantity of money in circulation.

Though the monetarist opinion is line with the postulate of the quantity theory of money, modern monetarists have made considerable modifications to the classical quantity theory of money. They do not support the classical idea that there is a direct variation between quantity of money in stock and changes in price level. They also disagree with classical proposition that, in the short run, the supply curve is vertical. They argued that, in practice, when there is reduction in money stock, output level first reduces and later, have effect on prices. Furthermore, in contrast with the classical economists, modern monetarists differentiate between the short run and long-run impact of the change in the quantity of money in stock. Monetarist further assert that, money in the long-run is neutral. According to them, money injected in the economy have no real effect but only cause changes in price levels.

\subsubsection{Structural theory of inflation}

In addition to the monetarist view of inflation, there is other group of economists categorized as the structuralist. The idea of structural theory of inflation according to Dwivedi (2009) was borne from the work of Myrdal, Streeten and other Latin American economist. The structuralist believes that, there are other factors that cause inflation apart from market power. The supporters of structural theories are of the opinion that, structural disturbances in a country causes inflation (Dutt \& Ros (2007). They opined that, economists frequently find out specific inflexibility, delays and other relevant features in developing countries in order to investigate the way economies adjust and their openness to development policies.

As indicated by Ezirim, Amuzie and Muoghalu (2012), the structuralist describes the long-run inflationary trend in developing countries in terms of "structural rigidities, market inadequacy and social tension, relative inelasticity of food supply, foreign exchange, contracts protective measures, rise in demand for food, fall in export earnings, stocking of import substitutions, industrialization, and political instabilities".

\subsubsection{Modern Theory of Inflation}

The modern method to inflation is in line with the theory of price determination. The price theory suggests that, in a competitive market, aggregate price is dependent on the variation in aggregate demand and aggregate supply factors. As indicated by John Maynard Keynes (1883-1946), the demand factors are called demand-pull inflation while the supply-factors are the cost-push inflation.

Demand pull inflation: This type of inflation is asserted to arise when aggregate demand far exceeds aggregate supply. It involves inflation increasing as real GDP also rises and unemployment falls According to Totonchi (2011), aggregate demand comprises consumption, investment and government expenditure. According to Dwivedi (2008) and Vaish (2011), the real indicators or causative factors of inflation include government expenses and taxes.

Cost push inflation: As indicated by Totonchi (2011), cost-push inflation results from the increase in wage normally enforced by labour unions and the increase in profit by employers. This was also affirmed by Alpanda, Kotze and Woglom (2010). They point out that, the pressure mounted by trade union activities result in an increase in the cost of production and wages. Too much pressure on employers to increase wages will cause them to increase prices of their product. Higher wages enable employees demand more of a product. This will in turn cause 
employers to increase prices of their product which will also induces labour union to demand more wages.

\section{Methodology, Data and Measurement}

\subsection{Theoretical Model Specification}

The study adopted the Solow-Swan model within a frame work of neoclassical economics which indicate that, exchange rate is a predictor of inflation rate (INFR) when augmented by additional variables. This is indicated below:

$$
I N F R_{t}=f\left(E X C R_{t}\right)
$$

The immediate question from the above equation is: what proportion of the variation in inflation rate that has not been accounted for by the variation in exchange rate? This suggest that there are other predictors of inflation rate. Solow (1956) decompose the rise in inflation rate into two categories: increase in exchange rate and growth of total factor productivity (TFP). The total factor productivity captures the unexplained variation not accounted for by exchange rate. To account for the other predictors, the inflation rate model employed for this study can be written as:

$$
I N F R_{t}=f\left(A_{t}, E X C R_{t}, e\right)
$$

whereINFR $R_{t}$ is the inflation rate at time $t, A_{t}$ is TFP which denote the effect of exogenous technological progress and " $e$ " represents the naperian $e$. By applying the Cobb-Douglas production function, equation (2) can be rewritten as:

$$
I N F R_{t}=A_{t} E X C R_{t}^{\beta_{1}} e^{\mu_{t}}
$$

The total factor productivity, $A_{t}$ is not constant but is dependent on the type of production function and the factors being studied.

\subsection{Empirical Model Specification}

The theoretical model described above was used as the basis for postulating the empirical model for this study. A review of literature on the determinant of inflation rate revealed that, there are various indicators that can affect total factor productivity $\left(A_{t}\right)$. In this study, money supply growth (GMS), monetary policy rate (MPR), and political instability (POI) were considered as the factors which affect $A_{t}$ as indicated below:

$$
A_{t}=f\left(G M S_{t}, M P R_{t}, P O I_{t}\right)
$$

Where, $G M S$ is the growth in money supply, $M P R$ is monetary policy rate, and $P O I$ denote political instability. Employing Cobb-Douglas production function, equation for can be written as:

$$
A_{t}=G M S_{t}^{\beta_{2}} M P R_{t}^{\beta_{3}}, P O I_{t}^{\beta_{4}}
$$

By substituting equation (5) into equation (3), the model can be rewritten as:

$$
I N F R_{t}=c E X C R_{t}^{\beta_{1}} G M S_{t}^{\beta_{2}} M P R_{t}^{\beta_{3}}, \mathrm{POI}_{t}^{\beta_{4}} e^{\mu_{t}}
$$

A log-linear model was obtained by taking natural logarithm of equation (6) resulting in equation (7) below:

$$
\ln \left(I N F R_{t}\right)=\ln c+\beta_{1} \ln E X C R_{t}+\beta_{2} G M S_{t}+\beta_{3} \ln M P R_{t}+\beta_{4} P O I_{t}+\mu_{t} \ln e
$$

Where, lne $=1$, lnc $=\beta_{0}$, equation (7) can be rewritten as:

$$
\ln \left(I N F R_{t}\right)=\beta_{0}+\beta_{1} \ln E X C R_{t}+\beta_{2} G M S_{t}+\beta_{3} \ln M P R_{t}+\beta_{4} P O I_{t}+\mu_{t}
$$

Where, $\beta_{0}$ is the intercept and $\beta_{1}, \beta_{2}, \beta_{3}$, and $\beta_{4}$ are parameters of the respective indicators.

Based on economic theory and the review of related literature, it is expected that:

$$
\beta_{1}>0, \beta_{2}>0, \beta_{3}>0 \text { and } \beta_{4}<0
$$

By employing the growth accounting model, equation (8) can be written as:

$$
\begin{aligned}
& \operatorname{lnINFR} R_{t}-\ln I N F R_{t-1}=\beta_{0}+\beta_{1}\left(\ln E X C R_{t}-\ln E X C R_{t-1}\right)+\beta_{2}\left(G M S_{t}-G M S_{t-1}\right) \\
& +\beta_{3}\left(\ln M P R_{t}-\ln M P R_{t-1}\right)+\beta_{4}\left(P O I_{t}-P O I_{t-1}\right)+\mu_{t}
\end{aligned}
$$

By introducing lag operator $\Delta$, equation can be written as:

$$
\Delta \ln \left(I N F R_{t}\right)=\beta_{0}+\beta_{1} \Delta \ln E X C R_{t}+\beta_{2} \Delta \ln G M S_{t}+\beta_{3} \Delta \ln M P R_{t}+\beta_{4} \Delta P O I_{t}+\mu_{t}
$$

The long-run model to be estimated as:

$$
\ln \left(I N F R_{t}\right)=\beta_{0}+\beta_{1} \ln E X C R_{t}+\beta_{2} G M S_{t}+\beta_{3} \ln M P R_{t}+\beta_{4} P O I_{t}+\mu_{t}
$$

The short-run relationship of the variables under study is estimated as:

$$
\begin{gathered}
\Delta \ln \left(\operatorname{INFR}_{t}\right)=\beta_{0}+\sum_{i=1}^{p} \alpha_{0} \Delta \operatorname{lnINF} R_{t-i}+\sum_{i=1}^{q 1} \beta_{1} \Delta \ln E X C R_{t-i}+\sum_{i=1}^{q 1} \beta_{2} \Delta G M S_{t-i} \\
+\sum_{i=1}^{q 1} \beta_{3} \Delta \ln M P R_{t-i}+\sum_{i=1}^{q 1} \beta_{4} \Delta P O I_{t-i} \\
+\rho E C M_{t-1}+\mu_{t}
\end{gathered}
$$

Where, $E C M_{t-1}$ is the error correction term lagged one period and the coefficient $\rho$ associated with the error correction term is the speed of adjustment to equilibrium. 


\subsection{Measurement of Variables and Sign Expectations}

The dependent variable in this study was inflation rate (INFR) while the independent macroeconomic variables that influence inflation rate were the Cedi to Dollar rate (EXCR), growth in money supply (RMS), monetary policy rate (MPR) and political business cycle (PBC) such as election year serving as a dummy variable. The rationale behind the choice of these variables was based on the availability of the series and it closes proxies, and theoretical and empirical review on the relationship between the variables.

\section{Dependent variable}

Inflation rate: In economic terms, inflation is defined as the "persistent increase in the over-all prices of goods and services in an economy within a period of time" (Blanchard, 2008). According to Ramlan and Suhaimi (2017), inflation is defined as the rate at which the general prices of goods and services increases and, subsequently, the purchasing power of currency is falls. When the prices of goods and services increase overtime, a unit of currency can purchase less goods and services. This suggest that, the purchasing power per unit of money is reduced when the prices of goods and services increases. A measure of inflation is inflation rate which is the annual percentage change in price index (consumer price index) over time (Mankiw, N. Gregory \& Reis, R. 2001a).

\section{Independent variable}

Exchange rate: In relation to this study, exchange rate is the price the Ghana Cedi relative to the price of the major trading currency, the US dollar. According to the literature review, fluctuation in exchange rate affect domestic inflation rate. The relationship between inflation rate and exchange rate was ascertain through a study conducted by Mahamadu and Abradu-Otoo (2003). They opined a long run equilibrium relationship between inflation and exchange rate and real income. The law of one price also influences exchange rate. The law supports the argument that, an increase in prices as a result of inflation normally happens in currency experiencing inflation. From this assertion, it can be concluded that, $\beta_{1}>0$.

Money supply: In the literature review, it was indicated that, generally, the key determinant of inflation is monetary phenomenon. However, Totonchi (2011) and Kemal (2006) opined that, in developing countries, inflation can be attributed the in the growth on money supply which far exceeds real output. When more money chases fewer goods, it causes firm to increase prices. The findings were in line with the quantity theory of money which indicate that, the quantity of money circulating in an economy affect prices of goods and services. This indicates that there is a positive relationship between growth in money supply and inflation rate. Due to lack of data on the quantity of money circulating in the Ghana economy, broad money supply was used as close proxy. According to Peterson and Adam (2016), in econometric modeling, there is a need to work with growth or returns instead of price. In view of this, the formula below was implemented to convert money supply to growth in money supply (GMS):

$$
G M S_{t}=\frac{M S_{t}}{M S_{t-1}}-1
$$

Where $G M S_{t}$ is the growth in money supply at time $t, M S_{t}$ is the quantity of money circulating at time $t$, and $M S_{t-1}$ is the quantity of money circulation at a one period lag. From the various empirical study reviewed and the quantity theory of money, a positive relationship exists between growth in money supply and inflation rate. Hence $\beta_{2}>0$

Monetary policy rate: The monetary policy rate (MPR) is one of the monetary policy tool used by Bank of Ghana (BOG). This is the rate at which commercial banks can access credit from central bank. The rate normally set at a level to meet inflation target. This indicates that, this variable has impact on inflation rate. There has been contrary opinion on the general impact of interest rate on inflation rate. Following the idea of the Fisher hypothesis, Ayub et al. (2014, p. 51) opined that there is a positive association between inflation and interest rate in any economy. Their argument was based on the conviction that, both inflation and interest rate are driven by monetary phenomenon which influences both demand and supply side of an economy (Semuel et al., 2015).

Geetha et al. (2011, p. 1) on the other hand opposed the idea of a positive relationship between inflation and interest rate. They based their opinion on the financial theory and argued that inflation rate which is mirrored by consumer price index (CPI) is a general upward movement of prices of goods and service and for that matter the general value of purchasing power would eventually depreciate due to so much money chasing few goods. Since interest rate and inflation rate are money driven, the inflation would decrease the demand for money which will also decrease interest rate on credit requested from financial institution (Geetha et al. 2011, pp. 1-3). Following the idea of Ayub et al. (2014, p. 51), it is expected that $\beta_{3}>0$

\section{Dummy variable}

Political instability: According to the structuralist, the long-run inflationary trend in most developing countries is partly due to structural rigidities, social tension, and political instabilities (Ezirim, Amuzie \& Muoghalu, 2010). The literature review revealed that political instability usually shortens policymakers' horizons which eventually leads to sub-optimal short term macroeconomic policies. It is also likely to cause frequent switch of economic policies which create volatility in inflation rate. In this study, the dummy variable, election year was used as close proxy for political instability (POI) that influence inflation rate. The political business cycle such as election year 
has influence on inflation. Usually the incumbent government usually manipulate political and fiscal policy as election year approach to increase their likelihood of wining the next election (Block, 2002). The impact is an increase in growth and a moderate rise in inflation rate before election (Hibbs, 2012). In this study, it was coded as 0 and 1 with 1 denoting election year and 0 as otherwise. It is expected that there will be a positive $\left(\beta_{4}>\right.$ $0)$ relationship between political instability (election year) and inflation rate.

\section{Estimation Technique}

\subsubsection{Unit root test}

A time series is said to have a unit root if its statistical properties such as its mean, variance and auto-covariance trends with time. When a series used in a regression model have unit root or not stationary, the standard conventions for asymptotic analysis will not be valid which will result in spurious relationship. In view of this, unit root test is relevant in time series modeling since most of the economic and financial time series by default exhibit trending behavior. One of the precondition for the use of Autoregressive Distributed Lag (ARDL) is that, none of the variables under study are at least I(2). In this study, the Augmented Dicker-Fuller (ADF) and the Phillips-Perron (PP) test for unit root was employed. Both the ADF and PP test the null hypothesis of the presence of a unit root (non-stationary). The lag-length for both the ADF and PP was based on Akaike Information Criteria (AIC) and Swartz Information Criterion (SIC).

Consider a simple AR (1) model:

$$
y_{t}=\phi y_{t-1}+\mu_{t}
$$

Subtracting $Y_{t-1}$ from both sides gives:

$$
\begin{array}{ll}
y_{t}-y_{t-1}=(\phi-1) y_{t-1}+\mu_{t} & \\
\Delta y_{t}=\rho y_{t-1}+\mu_{t} & \Delta y_{t}=(\phi-1) y_{t-1}+\mu_{t}
\end{array}
$$

Where, $\rho=\phi-1$

The null hypothesis of presence unit root against the alternative hypothesis of no unit root are respectively indicated below:

$$
\begin{aligned}
& H_{0}: \rho=0\left(Y_{t} \text { has unit root or non-stationary }\right) \\
& H_{1}: \rho<0\left(Y_{t} \text { has no unit root or stationary }\right)
\end{aligned}
$$

If the test statistics less than or equal to the critical value, the null hypothesis of presence of a unit root is rejected.

\subsubsection{Co-integration test}

Time series data with unit root often leads to spurious relationship and for that matter, differencing the series to make it stationary is relevant. However, the cointegration relationship between the variables are loss when the series are differenced. Cointegration test examines how series with unit root drift extensively away from equilibrium but when combined, they do not drift apart. In order to keep the long-run information between the variables, Granger (1981) and Engle and Granger (1987) proposed the idea of evaluating the existence of a long run cointegration relationship between group of variables. The maximum likelihood-based Johansen (1994) and Johansen-Juselius (1990) tests for cointegration has also been implemented by various researchers to establish cointegration relationship. As a result of the low power and other problems related with this approach to cointegration, the use of the Autoregressive Distributed Lag approach to cointegration has become popular among researchers. This study was centered on the use of the ARDL approach to cointegration.

\subsubsection{Autoregressive Distributed Lag (ARDL) Approach to Co-integration}

Autoregressive Distributed Lag Model (ARDL) plays and important role in analyzing economic phenomenon. In this study, the ARDL approach proposed by Pesaran et al. (2001) was employed to ascertain the long-run and short-run relationship between the variables under study. The rationale behind this choice was not only centered on the flexibility in using ARDL approach to co-integration. The researcher also took various factors into consideration. The relevance of using ARDL approach to co-integration was stressed on by Haug (2002). He argued that, compared to other approach to co-integration, ARDL is more robust and provide better result for small sample size.

In this study, semi-annual variables ranging from December 1990 to June 2017 indicating a small sample size of 54 observation was used in establishing co-integration relationship among the variables. Furthermore, both the long-run and short run relationship and parameters can be determined simultaneously. Laurenceson and Chai (2003) argued that, ARDL approach helps in avoiding problem that arises from series with unit root. The series employed in this study are a mix of I(0) and I(1). The Johansen $(1991 ; 1995)$ and the Johansen-Juselius (1990) approach to co-integration requires that, all series are I(1) and therefore, this method of co-integration cannot be employed in this study. Due to these setbacks, the ARDL approach to co-integration was appropriate for the study.

The ARDL framework for equation (12) and (13) are as follows:

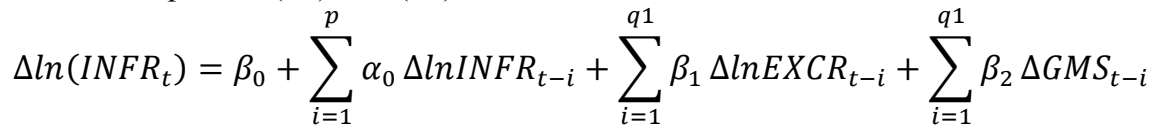




$$
\begin{aligned}
& +\sum_{i=1}^{q 1} \beta_{3} \Delta l n M P R_{t-i}+\sum_{i=1}^{q 1} \beta_{4} \Delta P O I_{t-i}+\phi_{1} \operatorname{lnINFR}_{t-i} \\
& +\phi_{5} \mathrm{POI}_{t-i}+\mu_{t} \\
& +\phi_{2} \ln E X C R_{t-i}+\phi_{3} G M S_{t-i}+\phi_{4} \ln M P R_{t-i}
\end{aligned}
$$

In the above equations, $\phi_{i}$ is the long run multipliers, $\beta_{0}$ is the drift, and $\mu_{t}$ is the random disturbance.

In order to obtain the optimal lags for each series, the ARDL model estimates $(q 1+1)^{n}$ number of regressions where $q 1$ is the maximum number of lags to be used and $n$ is the number of series in the equation. Out of the $(q 1+1)^{n}$, the optimal model was identified using the Schwartz-Bayesian Criteria (SBC) and Akaike Information Criteria (AIC). In this study, the optimal model was obtained on the basis of their prediction power by comparing the prediction errors.

\subsubsection{Bounds Test Procedure}

After estimating the optimal lag of the ARDL model in equation (16), the next step is to estimate the ARDL model in equation (16) using the ordinary least squares (OLS) and then test for the existence of a long-run relationship among the by conducting an F-test for the joint significance of the coefficients of the lagged levels of the variables.

The null hypothesis of non-existence of co-integration relationship together with the alternative hypothesis are stated respectively as:

$$
\begin{aligned}
& H_{0}: \phi_{1}=\phi_{2}=\phi_{3}=\phi_{4}=\phi_{5}=0 \\
& H_{1}: \phi_{1} \neq \phi_{2} \neq \phi_{3} \neq \phi_{4} \neq \phi_{5} \neq 0
\end{aligned}
$$

The test which normalizes on $I N F R_{t}$ is denoted by $F_{I N F R}(\mathrm{~L} E X C R \mid, G M S$, LMPR, POI). Paseran et al. (2001) provided two value for the asymptotic distribution of the F-statistics, the lower bounds assuming $\mathrm{I}(0)$ and the upper bounds based on the assumption that all the variables are I(1). If the F-statistics is less than the critical value of the lower bounds, it indicate that all the variables are $\mathrm{I}(0)$ indicating no long-run relationship. However, if the Fstatistics exceeds the critical value of the upper bounds, it indicates a co-integration relationship between the variables. The test inconclusive if the F-statistics is within I( 0$)$ and I(1). This was one of the main reason for a unit root test. The approximate critical value proposed by Paseran and Paseran (1997) was based on large sample size. Due to the small sample size used in this study, the range of the appropriate critical value developed by Narayan (2004) was used as a yard stick in making inference on the co-integration relationship among the variables. According to him, a critical value ranging from "2.962 -3.91" is appropriate for a small sample size if the probability of committing Type 1 error is set to 5 percent. If the result of the bound test yields a positive result, the next step is to estimate a separate restricted Error Correction Model (ECM) that correspond with the best ARDL model identified.

From equation (16) the Error Correction Model (ECM) is estimated as:

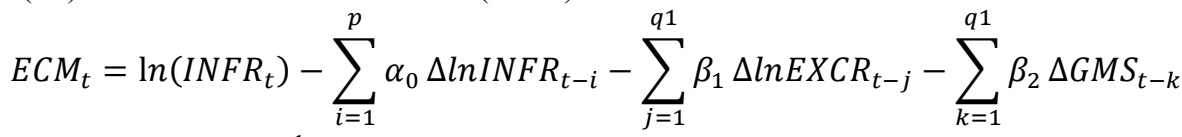

$$
\begin{aligned}
& -\sum_{l=1}^{q 1} \beta_{3} \Delta \ln M P R_{t-l}-\beta_{0}
\end{aligned}
$$

The error correction term indicates the speed of adjustment to equilibrium when they are disturbed. It is expected that the error correction term is statistically significant and negative. When this objective is achieved, it indicates that any shock or innovation in the short run was corrected in the long-run. The grater the absolute value of coefficients of the error correction term, the faster it adjusts to equilibrium.

To ensure that the ARDL model is robust, the researcher conducted diagnostic and stability on the model. The diagnostic test involves serial correlation, normality and heteroskedasticity associated with the selected model. The cumulative sum (CUSUM) and cumulative sum of squares (CUSUMSQ) statistics was employed to ascertain the stability of the coefficient. The null hypothesis of stable coefficient is rejected if the plot of the CUSUM and CUSUMSQ statistics is outside the critical bounds of five percent level of significance.

\section{Empirical Results}

\subsection{Descriptive Statistics}

The result of descriptive statistics of the series under study is displayed in table 4.0. The mean of all the variables were found to be positive. It is also clear from table 4.0 that Inflation rate (INFR), Exchange rate (EXCR), are highly skewed to the right as compared to money supply growth (GMS) and monetary policy rate (MPR). The Jarque-Beratest indicate that, apart from monetary policy rate (MPR)and growth in money supply (GMS) which were found to be normally distributed at levels, all the other variables deviate from normality. The coefficient of kurtosis for all the variables indicate a leptokurtic distribution. 
Table 4.0 Summary Statistics of the Variables

\begin{tabular}{|l|c|c|c|c|}
\hline & INFR & EXCR & GMS & MPR \\
\hline Mean & 20.20547 & 1.168700 & 0.155393 & 24.76415 \\
\hline Median & 17.00000 & 0.904700 & 0.157983 & 22.50000 \\
\hline Maximum & 70.80000 & 4.362900 & 0.419560 & 45.00000 \\
\hline Minimum & 8.400000 & 0.036700 & -0.021201 & 12.50000 \\
\hline Std. Dev. & 12.81158 & 1.204575 & 0.118002 & 10.05686 \\
\hline Skewness & 2.109061 & 1.416523 & 0.423800 & 0.747361 \\
\hline Kurtosis & 7.821001 & 4.137795 & 2.222254 & 2.510117 \\
\hline & & & & 5.463814 \\
\hline Jarque-Bera & 90.61808 & 20.58328 & 2.922316 & 0.065095 \\
\hline Probability & 0.000000 & 0.000034 & 0.231967 & 1312.500 \\
\hline & & & & 5259.302 \\
\hline Sum & 1070.890 & 61.94110 & 8.235842 & \\
\hline Sum Sq. Dev. & 8535.099 & 75.45200 & 0.724070 & 53 \\
\hline
\end{tabular}

Note: Std. Dev. is the standard deviation while Sum Sq. Dev. represents sum of squared deviation.

Source: computed by author using Eviews 10.0 Package

\subsection{Result of Unit root (stationary) test}

In the ARDL approach to cointegration, pretesting of the series for the unit root is not a requisite. However, One of the precondition for the use ARDL is that, none of the variables under study be at least I(2). To verify this, the ADF test and Phillips-Perron (PP) unit root test was performed on all the variables at levels and after first difference to ascertain if they are $\mathrm{I}(2)$ or not. The optimal lag selection was based on based on automatic selection using the Schawrtz-Bayesian Criteria (SBC), Akaike Information Criteria (AIC) the $\overline{R^{2}}$ criteria or the Hannan and Quinn (H-Q) criteria. Table 4.1 indicate the result of the ADF test with intercept and trend. The findings revealed that, the null hypothesis of presence of unit root for some of the variables cannot be rejected indicating that they have unit root. However, all the variables after first difference were found to be statistically significant indicating that none of the series are $\mathrm{I}(2)$

Table 4.1 Results of ADF test for Unit Root with constant and trend

Levels First Difference

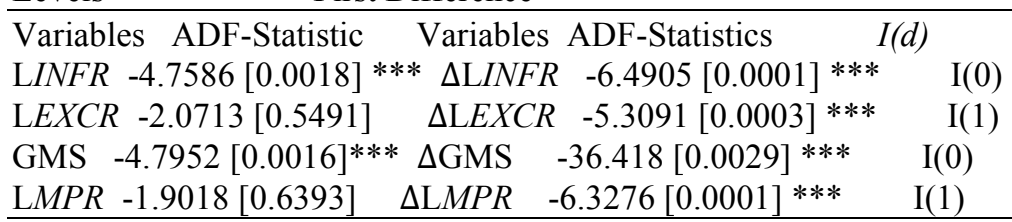

Source: computed by author using Eviews 10.0 Package

The result of the Phillips-Perron test with constant and trend for the presence of a unit is displayed in table 4.4. The result also affirmed that most of the variables have unit root at levels since most the p-value were not significant and for that matter, the we fail to reject the null hypothesis of the presence of unit root at any of the three conventional levels of significance with the exception of money supply growth (GMS) which was statistical significant at levels. The variables were first difference and the P-P test of the presence of unit root was run. The result indicates a rejection of the null hypothesis of the presence of unit root indicating that, the series are stationary. Since the variables are either I(1) or I(0) and none I(2), the ARDL approach to cointegration seems to be best in establishing both the long-run and short-run cointegration relationship.

Table 4.2 Result of Phillips-Perron $(P-P)$ test for Unit Root with constant and trend

\begin{tabular}{|c|c|c|c|}
\hline First Di & fference & & \\
\hline Variables P-P-Statistics & Variables & ADF-Statistics & $I(d)$ \\
\hline LINFR $\quad-3.0157[0.1378]$ & $\triangle \mathrm{LINFR}$ & $-7.7555[0.0001] * * *$ & $\mathrm{I}(1)$ \\
\hline $\mathrm{LEXCR} \quad-1.6847[0.7443]$ & $\triangle \mathrm{LEXCR}$ & $-5.1767[0.0005] * * *$ & $\mathrm{I}(1)$ \\
\hline GMS $-17.0567[0.0001]$ & $* * * \quad \Delta \mathrm{GMS}$ & $-80.626[0.0001] * * *$ & $\mathrm{I}(0)$ \\
\hline $\mathrm{LMPR} \quad-1.72500[0.7262]$ & $\triangle \mathrm{L} M P R$ & $-5.9493[0.0001] * * *$ & $\mathrm{I}(1)$ \\
\hline
\end{tabular}

Note: $* * *, * * *$ indicates the rejection of the null hypothesis of non- stationary at $1 \%, 5 \%, 10 \%$ level of significance respectively, $\Delta$ is the first difference. Values in parenthesis are the P-values. 
Source: Computed by author using Eviews 10.0 package

\subsection{ARDL Approach to Co-integration Result}

The result of the null hypothesis of non-existence of co-integration relationship is displayed in table 4.3. According to Narayan (2004), a critical value ranging from "2.962 -3.91" is appropriate for small sample size. The result of the bound test was statistically significant since F-statistics (5.5878) far exceeds the critical value of the upper bounds at all four conventional levels of significance. This indicate a co-integration relationship between the variables.

Table 4.3 Bounds Test Results for Co-integration

F-Bounds Test Null Hypothesis: No levels relationship

\begin{tabular}{lcrlr}
\hline \hline Test Statistic & Value & Signif. & $\mathrm{I}(0)$ & $\mathrm{I}(1)$ \\
\hline \hline F-statistic & $5.587829^{* * *}$ & $10 \%$ & 2.45 & 3.52 \\
$\mathrm{~K}$ & 4 & $5 \%$ & 2.86 & 4.01 \\
& & $2.5 \%$ & 3.25 & 4.49 \\
& & $1 \%$ & 3.74 & 5.06 \\
\hline \hline
\end{tabular}

Note: *** denotes statistical significance at the $1 \%$ level and $K$ is the number of regressors Source: Computed by author using Eviews 10.0 package

\subsection{Estimated long-run coefficient using ARDL}

The estimated long-run estimate based on Akaike Information Criteria (AIC) is displayed in table 4.4. The selected $A R D L(2,0,4,4,2)$ passes the standard diagnostic test. The coefficients denote the long run elasticities of the variables.

The findings displayed in table 4.4 revealed that exchange rate (EXCR) has a negative impact on inflation rate but was not statistically significant in the long run. Growth in money supply (GMS) has a positive significant impact on inflation rate (INFR) in the long-run. A unit increase in money supply growth will increase inflation rate by 4.288 percent. The findings suggest that, there is significant long run relationship between inflation rate and money supply. The result support the idea of monetarist theory of inflation which indicate that, price level changes with a proportionate change in the quantity of money in circulation. Research on the long run cointegration relationship done in developed countries indicate conflicting result. Tang and Lean (2007) study in the Malaysian economy indicate a negative significant relationship between money supply and inflation while Ndanshau (2010) did not observe any significant relationship. This might be due to the type of data employed, the methodology used and the level of inflation. In a study conducted by Grauwe and Polan (2005) to ascertain the association between money supply and inflation in 160 countries, it was clear that, in countries with high inflation rate, a significant association between inflation and money was found while in countries with extremely low inflation rate, the long-run association cannot be easily determined. De Grauwe and Polan (2001) affirmed this by removing series with high inflation. They found out that, there was no significant association between inflation and growth in money supply. In a similar study conducted by Thornton (2008) by incorporating 36 African countries, it was affirmed that, for countries with at least 11 percent inflation, money growth rate is a strong determinant of inflation. Ghana and other African countries has once recorded a three-digit inflation (Anwar \& Islam, 2011; Dua \& Gaur, 2009; Loungani \& Swagel, 2001). Inflation data reported by the Institute of Economic Affairs (IEA), Ghana on the assessment of inflation trends in Ghana from the period ranging from 1979 2009revealed that, Ghana for a long period has experience high level of inflation. According to IEA, monetization is the main driving force of inflation. The descriptive statistics in table 4.0 clearly affirmed the findings that, Ghana has constantly been experiencing a high level of inflation. Semi-annual data ranging from December 1990 to June 2017 on inflation rate (INFR) indicate an average inflation rate of 20.2 percent with maximum inflation of $70.8 \%$ and a minimum of $8.4 \%$. The findings obtained in the case of Ghana was in line with the findings obtained by previous researchers whose result indicate that, for countries with low inflation, the impact of money supply on inflation is rarely seen (De Grauwe, Polan, 2001; Thornton, 2008; Mahamadu \& Philip 2003).

The association between monetary policy rate and inflation rate was found to be significant and had the expected positive sign in the long run. The findings indicate that, when the central bank increase its rate by 1 percent, inflation rate will shoot up by 0.806 percent in the long run. Though there has been various debate on the general impact that changes in monetary policy rate had on inflation rate, the finding of the study was in line with the Ayub et al. (2014, p. 51) who opined that, there is a positive association between inflation and interest rate in any economy since both inflation rate and interest rate are driven by monetary phenomenon. One of the mandate 
of Monetary Policy Committee in Ghana is to implement policy in the areas of money, banking and credit with the main aim of minimizing volatility in inflation rate. A significant and positive association between inflation rate and monetary policy rate indicate that, monetary policy rate is an effective tool that the central bank can manipulate in stabilizing economic activities and meeting inflation target.

The result displayed in in table 4.4 also indicate the impact that political business such as election year has on inflation rate. The relationship between inflation and election year was negative and insignificant. This indicate that, in the long run, political business cycle such as election year has no significant impact on inflation rate.

Table 4.4 Estimated Long Run Coefficients using the ARDL Approach

\begin{tabular}{ccccc}
\hline \multicolumn{5}{c}{ ARDL $(2,0,4,4,2)$ selected based on AIC Dependent variable: L(INFR) } \\
\hline \hline Variable & Coefficient & Std. Error & t-Statistic & Prob. \\
L(EXCR) & -0.028057 & 0.083230 & -0.337105 & 0.7382 \\
GMS & 4.288103 & 2.138870 & 1.865406 & $0.0372^{* *}$ \\
L(MPR) & 0.806027 & 0.220262 & 3.659405 & $0.0009^{* * *}$ \\
POI & -0.337630 & 0.298114 & -1.132553 & 0.2658 \\
C & -0.223001 & 0.774371 & -0.287978 & 0.7752 \\
\hline \hline
\end{tabular}

Note: *,**,*** statistically significant at 10, 5 and 1 percent level of significance

\subsection{Estimated short-run Error Correction Model}

The presence of co-integration relationships among the variables under study suggests the estimation of Error Correction Model (ECM) to ascertain the dynamic behaviour of the inflation rate equation. The error correction term that estimated the short-run adjustments to equilibrium is given as:

$$
\begin{aligned}
& E C M=L I N F R+0.028 * L E X C R-4.288 * G M S \\
& -0.806 * L M P R+0.338 * P O I \\
& +0.223
\end{aligned}
$$

The result of the short run dynamics of the inflation rate (INFR) is displayed in table 4.5. The coefficient of determination was found to be 0.8081 indicating that approximately 81 percent of the variation in inflation rate can be explained by the variation in the predictor variables. Also, a Durbin-Watson statistic of approximately 2.128 indicate the absence of autocorrelation in the residual. The error correction model was highly significant $(\mathrm{F}=12.637$, $\mathrm{P}$-value $=0.0001)$ at 1 percent level of significance indicating a goodness of fit of the model. The results also revealed that, the coefficient of a period lag of the error correction term $E C M(-1)$ has the expected negative sign $(-0.42771)$ and significant at 1 percent. This statistic shows that, any disequilibrium in the previous period shocks in inflation rate will be corrected back to equilibrium in the current period at a speed for 43 percent indicating a slow adjustment toward equilibrium.

The result displayed in table 4.5 also shows the short run dynamics of the coefficient of the model. The findings indicate that, a positive insignificant association between inflation (INFR) and growth in money supply (GMS). The finding was consistent with study conducted by Kiganda (2015) who found an insignificant positive association between inflation rate and money supply. However, a two-period and a three-period lag of money supply growth (GMS) have a significant negative impact on inflation rate in the short run at $5 \%$ level of significance. The findings did not conform to the theorized positive impact of growth in money supply and inflation. This suggest that, if the previous two period lag and a previous three period lag of growth in money supply (GMS) is increase by a unit, inflation rate will decrease by 1.19 percent and 1.27 percent respectively in the short-run.

Table 4.5 also revealed that the coefficient of a period lag of inflation rate is positive and statistically significant at 1 percent. This indicate that an increase previous period inflation rate by 1 percent will result in 0.58496 percent increase in current period inflation rate in the short run. Furthermore, the result clearly indicates a positive significant relationship between monetary policy rate (MPR) and inflation rate in the short run. A 1 percent increase in MPR will result in 1.64 percent increase in inflation rate in the short run. It was also established that previous monetary policy rate has a negative and significant impact on inflation at 10 percent level of significant but insignificant at 5 percent level of significance. Therefore, in the short run, previous monetary policy rate has no significant impact on inflation rate.

Concerning the dummy variable, election year, it was realized that, it has a significant negative impact on inflation indicating that, there is no evidence of any inflation jumps during election season in the short run. This suggest that, the act of the incumbent government is archetypal a "time inconsistent act". This step convinces potential the electorate of the government competence using monetary phenomenon. This postpones the burden of inflation to the future in order to win the present election (Hibbs, 2012). The finding was contrary to the political 
business cycle theory which opined that, prior to election, the incumbent government manipulates fiscal policy to increase the likelihood of winning the next election which increase growth and leads to a moderate rise in inflation rate (Hibbs, 2012). The result from the study cannot substantiate the idea that, government manipulation of fiscal policy in election year increase inflation rate that year and thereafter. There is therefore a need of further research to validate the short run association between inflation and election year.

Table 4.5 Estimated Short-Run Error Correction Model using the ARDL Approach

ARDL $(2,0,4,4,2)$ selected based on AIC Dependent Variable: DL(INFR)

\begin{tabular}{ccccc} 
Regressors & Coefficient & Std. Error & t-Statistic & Prob. \\
\hline \hline C & -0.095382 & 0.028575 & -3.337912 & $0.0022^{* * *}$ \\
$\Delta$ L(INFR(-1)) & 0.584957 & 0.110445 & 5.296378 & $0.0000^{* * *}$ \\
$\Delta($ GMS $)$ & 0.285793 & 0.352267 & 0.811295 & 0.4232 \\
$\Delta($ GMS(-1)) & -0.595720 & 0.497679 & -1.196995 & 0.2401 \\
$\Delta($ GMS(-2) $)$ & -1.188037 & 0.514243 & -2.310261 & $0.0275^{* *}$ \\
$\Delta($ GMS(-3)) & -1.272089 & 0.356570 & -3.567572 & $0.0012^{* * *}$ \\
$\Delta L($ MPR $)$ & 1.648928 & 0.231147 & 7.133661 & $0.0000^{* * *}$ \\
$\Delta L($ MPR(-1)) & -0.461678 & 0.271923 & -1.697824 & $0.0992^{*}$ \\
$\Delta L($ MPR(-2) $)$ & -0.180013 & 0.226160 & -0.795953 & 0.4319 \\
$\Delta L($ MPR(-3)) & -0.293722 & 0.195654 & -1.501237 & 0.1431 \\
$\Delta($ POI) & -0.166938 & 0.047191 & -3.537505 & $0.0013 * * *$ \\
$\Delta($ POI(-1)) & 0.144887 & 0.049034 & 2.954835 & $0.0058^{* * *}$ \\
ECM(-1) & -0.427719 & 0.076291 & -5.606384 & $0.0000^{* * *}$ \\
\hline \hline R-squared & 0.808143 & Mean dependent var & -0.001930 \\
Adjusted R-squared & 0.744191 & S.D. dependent var & 0.308896 \\
S.E. of regression & 0.156232 & Akaike info criterion & -0.652639 \\
Sum squared resid & 0.878703 & Schwarz criterion & -0.150727 \\
Log likelihood & 28.98965 & Hannan-Quinn criter. & -0.462214 \\
F-statistic & 12.63665 & Durbin-Watson stat & 2.127988 \\
Prob(F-statistic) & $0.000000 * * *$ & & \\
\hline \hline
\end{tabular}

Note: *,**,*** statistically significant at 10, 5 and 1 percent level of significance

Source: Computed by author using Eviews 10.0 package

\subsection{Diagnostic Test of the ECM}

The cogency of the model is dependent on it fit and stability. In this section, diagnostic tests on against serial correlation using Breusch-Godfrey Serial Correlation LM Test, heteroscedasticity using Breusch-Pagan-Godfrey statistics, and normality of errors Jarque-Bera test was performed. In addition, this section also presents the result of stability of the parameters using the cumulative sum of recursive residuals (CUSUM) and the CUSUM of square (CUSUMSQ).

\subsubsection{Residual diagnostic result Normality test}

The result of goodness of fit test of whether the residuals have skewness and kurtosis matching a normality distribution is displayed in figure 4.0. The null hypothesis of assumption of normality of residuals was not rejected since it was not statistically significant $(\mathrm{JB}=2.4641$, $\mathrm{p}$-value $=0.291)$. Hence the assumption of normality was not violated. 
Figure 4.0 Result of normality of residuals

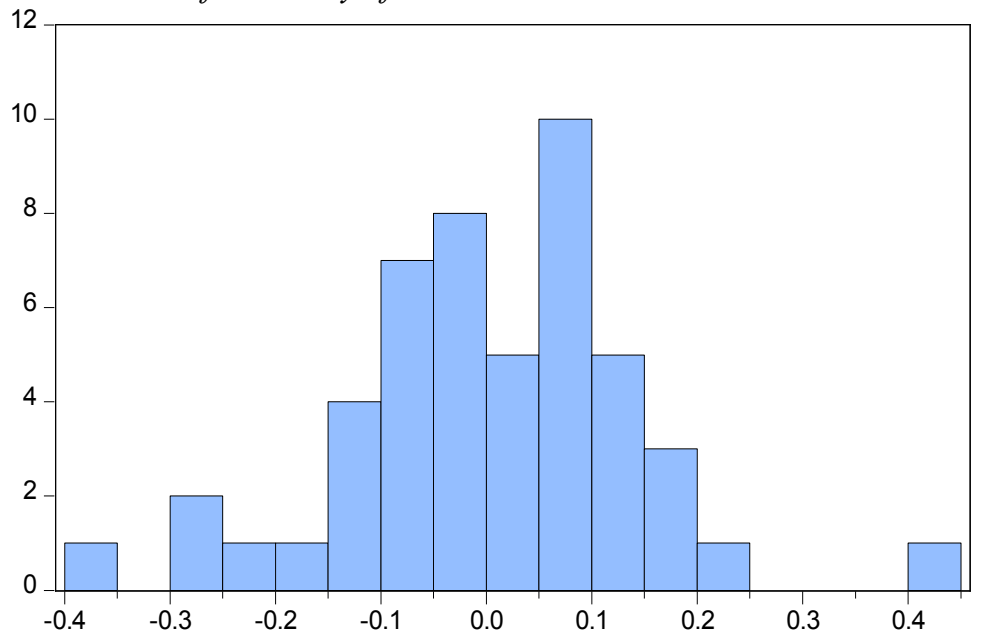

Series: Residuals

Sample 6/01/1993 6/01/2017

Observations 49

Mean $\quad 9.78 \mathrm{e}-16$

Median $\quad 0.004333$

Maximum $\quad 0.404802$

Minimum $\quad-0.362547$

Std. Dev. $\quad 0.135301$

Skewness $\quad-0.107391$

Kurtosis $\quad 4.077386$

Jarque-Bera $\quad 2.464073$

Probability $\quad 0.291698$

Source: Generated by author using Eviews 10.0 package

\section{Breusch-Godfrey serial correlation LM test}

The Breusch-Godfrey Serial Correlation LM Test was run to test the null hypothesis of no serial correlation. The result presented in Table 4.6 indicate an Obs*R-squared value of 0.4769 with a p-value of 0.7878 which far exceeds the $5 \%$ level of significance, meaning that we fail to reject the null hypothesis of no serial correlation in the model.

Table 4.6 Result of Breusch-Godfrey Serial Correlation LM Test

$\begin{array}{llll}\text { F-statistic } & 0.147437 & \text { Prob. F(2,30) } & 0.8635 \\ \text { Obs*R-squared } & 0.476941 & \text { Prob. Chi-Square (2) } & 0.7878\end{array}$

Source: Computed by author using Eviews 10.0 package

\section{Breusch-Pagan-Godfrey Heteroskedasticity Test}

The result of Breusch-Pagan-Godfrey test of the null hypothesis of no heteroscedasticity against alternative hypothesis of heteroscedasticity is displayed in table 4.7 . We fail to reject the null hypothesis of no heteroscedasticity $\left(\mathrm{Obs}^{* \mathrm{R}}\right.$-squared=19.033, p-value=0.267) indicating a homoscedasticity of variance.

Table 4.7 Heteroscedasticity Test: Breusch-Pagan-Godfrey

\begin{tabular}{llll}
\hline \hline F-statistic & 1.270262 & Prob. F(16,32) & 0.2737 \\
Obs*R-squared & 19.03299 & Prob. Chi-Square(16) & 0.2670 \\
Scaled explained SS & 12.49012 & Prob. Chi-Square(16) & 0.7096 \\
\hline \hline
\end{tabular}

Source: Computed by author using Eviews 10.0 package

4.6.2 Stability diagnostic result

The cumulative sum of recursive residuals (CUSUM) and the CUSUM of square (CUSUMSQ) tests was run to assess the stability of the parameters (Pesaran and Pesaran (1997)). Figure 4.1 and figure 4.2 plot of the CUSUM and CUSUMSQ is within the critical bands of the $95 \%$ confidence interval. This suggests that the parameters are stable over the range of period under study. 
Figure 4.1 Result of CUSUM stability test of ECM

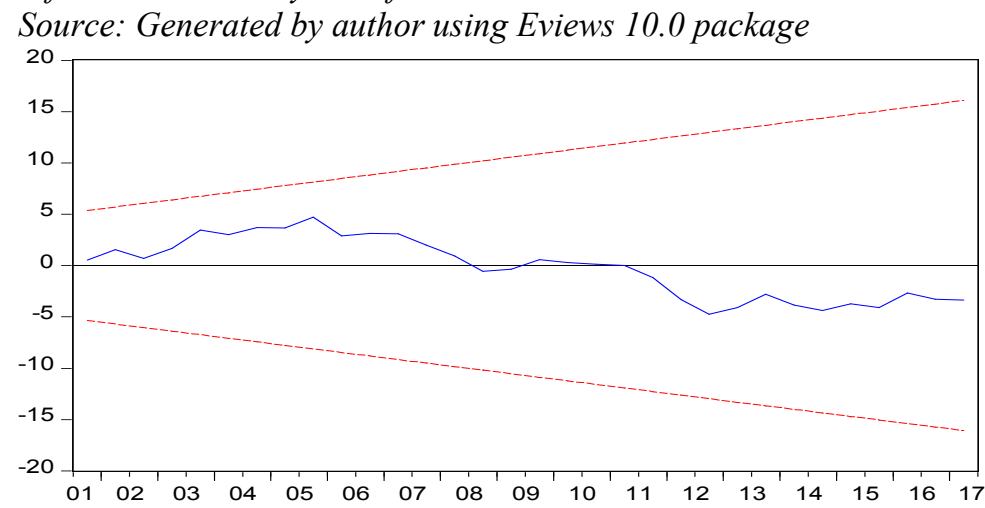

Figure 4.2 Result of CUSUMQ stability test of ECM

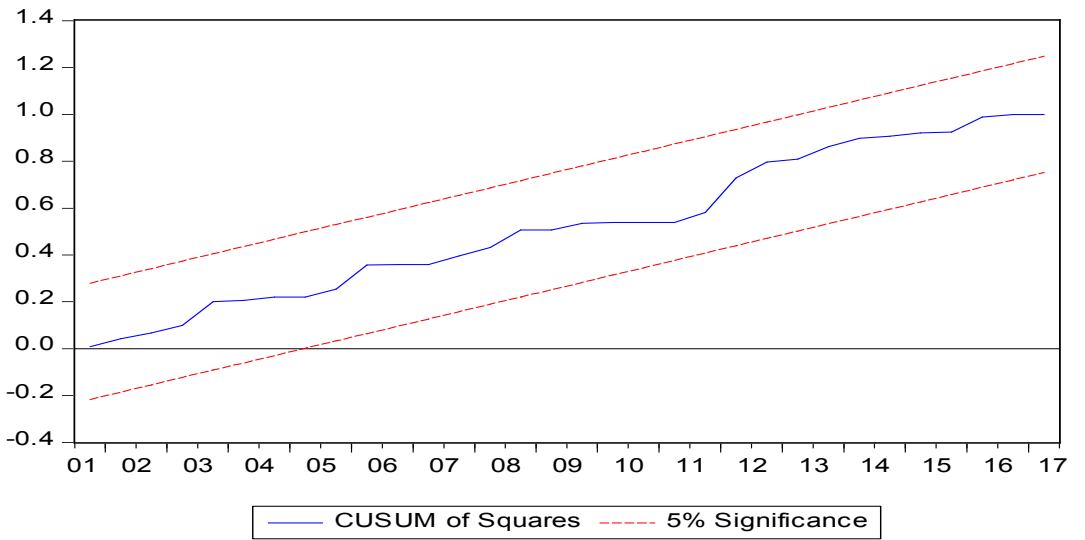

Source: Generated by author using Eviews 10.0 package

\section{Conclusion}

The study revealed a long run positive relationship between inflation and money supply growth. The findings from the study was in line with the monetarist theory of inflation which argued that, inflation is a monetary phenomenon. It also supports the empirical review that for countries with high levels of inflation, the impact of money supply on inflation is significant compared to countries to with low inflation rate indicating that the impact of money supply on inflation is country specific. The findings suggest that, the central bank can achieve inflation target by regulating the quantity of money circulating in the economy.

In the short run, no significant association was found between money supply and inflation. Political instability during election year that arises from the manipulation of fiscal policy in order for the incumbent government to increase the likelihood of winning the next election was found to have a negative and significant impact on inflation rate in the short run. The finding was contrary to the opportunistic models of the political cycle theory. Further research need to be conducted to validate the association between the variables.

\section{Reference}

Adu G, Marbuah G. (2011). Determinants of inflation in Ghana: An empirical investigation. South African J. Econ.;79(3):251-269.

Aikaeli, J. (2007). "Money and inflation dynamics: a lag between change in money supply and the corresponding inflation process in Tanzania". Bank of Tanzania working paper.

Alpanda, S., Kotze, K. and Woglom, J. (2010). Should Central Banks of Small Open Economies Respond to Exchange Rate Fluctuations? The Case of South Africa. Economic Research Southern Africa, Working Paper, p. 174

Anwar S, Islam I. (2011). Should developing countries target low, single digit inflation to promote growth and employment? Geneva, ILO EWP 87

Ayub, G., Rehman, N. U., Iqbal, M., Zaman, Q., \& Atif, M. (2014). Relationship between inflation and interest rate: Evidence from Pakistan. Research journal of recent Sciences,3(4),51-55

Bakare A.S (2011); "A Theoretical Analysis of Capital Formation and Growth in Nigeria" Far East Journal of 
Psychology and Business Vol 3. No 1

Bank of Ghana (2013). Bank of Ghana Monetary Policy Report: Inflation Outlook \& Analysis, Accra

Blanchard, O. (2008). Macroeconomics, 5nd ed. Upper Saddle River, N.J., Prentice-Hall,

Blanchard, O. (2000). Macroeconomics (2nd ed.). Englewood Cliffs, N.J: Prentice Hall.

Block SA (2002). Political business cycles, democratization, and economic reform: The case of Africa. J. Dev. Econ.;67(1):205-228

Burns, Alvin C. and Ronald F. Bush (2010), Marketing Research, 6th Edition, textbook and instructor's manual, Pearson Education, Inc. publishing as Prentice Hall.

Campillo, M., Miron, J., 1997. Why does inflation differ across countries? In: Romer, C., Romer, D. (Eds.), Reducing Inflation: Motivation and Strategy. University of Chicago Press, Chicago, IL, pp. 335-357

Cheng, M.Y., Tan, H.B. (2002), Inflation in Malaysia. International Journal of Social Economics, 29(5), 411-425

De Grauwe, P. and M. Polan (2005), ìIs ináation always and everywhere a monetary

phenomenon? Scandinavian Journal of Economics, 107(2), pp. 239-59.

Dua P, Gaur U. (2009). Determination of inflation in an open economy Phillips curve framework: The case of developed and developing Asian countries, Delhi, CDE WP178

Dutt, Amitava K. \& Ros, Jaime, (2007). "Aggregate demand shocks and economic growth," Structural Change and Economic Dynamics, Elsevier, vol. 18(1), p. 75-99

Dwivedi, D N. (2009). Managerial Economics, 7th ed., Vikas Publishing House, Delhi, India.

Ezirim, C. B., Amuzie, E. and Michael I. Muoghalu, M. (2012). Autoregressive Distributed Lag Analysis of Interdependencies Between Inflation and Exchange Rates in Sub-Saharan Nigeria. The IABPAD Conference Proceedings Dallas, Texas, Vol. 9, No. 2, pp. 1082-1093

Geetha, C., Mohidin, R., Chandran, V. V., and Chong, V. (2011). The relationship between inflation Growth in Nigeria. The Empirical Economics Letters, 1100-1115.

Grauwe, P.D., Polan, M. (2005), Is inflation always and everywhere a monetary phenomenon? Journal of Economics, 107(2), 239-259.

Haug, A.A., (2002). Temporal aggregation and the power of cointegration tests: A monte Carlo study. oxford Bulletin of Economics and Statistics, 64(4): 399-412

Hibbs DA. (2012). Political Parties and Macroeconomic Policy. Am. Politcal Science. Rev.;71(14):1467-1487.

Hossain, T. and Islam, N. (2013). An Economic Analysis of the Determinants of Inflation in Bangladesh, The International Journal of Social Sciences, Vol.11, No.1; 29-36

Hussain, M. E., and Haque, M. (2017). Empirical Analysis of the Relationship between Money Supply and Per Capita GDP Growth Rate in Bangladesh. Journal of Advances in Economics and Finance, 2(1): 54.

Isakova A. (2007). Modeling and forecasting inflation in developing countries: The case of economies in central Asia. Praha.

Johansen, S. and K. Juselius (1990). "Maximum Likelihood Estimation and Inference on Cointegration with Applications to Demand for Money" Oxford Bulletin of Economics and Statistics 52, 169-210.

Johansen, S. and K. Juselius (1994), "Identification of the Long-Run and the Short-Run Structure. An Application to the ISLM Model”, Journal of Econometrics, 63, 7-36.

Kemal, M. A., (2006), “Is Inflation in Pakistan a Monetary Phenomenon?” The Pakistan Development Review 45: 2 , pp. $213-220$

Khandan, A., and Hosseini, S. M. (2016). Determinants of Inflation: A case study of Iran. Applied Economics and Finance, 3(4).

Kiganda, E. O., (2015). "Relationship between Inflation and Money Supply in Kenya," Journal of Social Economics, Research Academy of Social Sciences, vol. 2(2), pages 63-83.

Kwakye, J. K. (2010), “Assessment of Inflation Trends, Management and Macroeconomic Effects in Ghana". IEA Monograph, No. 28

Loungani P, Swagel P. (2001). Sources of Inflation in Developing Countries. WP/01/198

Mahamadu. B. and Abradu-Otoo, P. (2003). Monetary growth, exchange rates and inflation in Ghana: An error correction analysis, Working Paper, WP/BOG

Malhotra, N.K, Birks, D. F, (2007) Marketing Research: An Applied Approach Marketing Research: An Applied Approach. Prentice Hall/Financial Time

Mankiw, N. G. (2002). "Macroeconomics" (5th ed.). Worth. Measurement of inflation is discussed in Ch. 2 , pp. 22-32; Money growth \& Inflation in Ch. 4, pp. 81-107; Keynesian business cycles and inflation in Ch. 9 , pp. 238-255.

Mankiw, N. Gregory and Reis, R. (2001a) "Sticky Information versus Sticky Prices: A Proposal to Replace the New Keynesian Phillips Curve," NBER Working Paper no. 8290. Quarterly Journal of Economics, forthcoming.

Narayan, P. K. and Narayan, S. (2005) Are Exports and Imports Cointegrated? Evidence from 22 Least Developed Countries, Applied Economics Letters, 12, 375-378 
Ndanshau, M. A. (2010). Money and other determinants of inflation: the case of Tanzania. Indian journal of economics and business, Volume: 9 Source Issue: 3, ISSN: 0972-5784

Ndanshau, M. O. A. (2010), "Money and other determinants of inflation: The case of Tanzania", Indian Journal of Economics and Management, University of Dar es Salaam

Patuti, A., \& Tatulescu, A. (2013). Empirical evidence for the quantity theory of money: Romania -A case study. Romanian Statistical Review, (11), 12-19.

Perevalov N, Maier P. (2010). On the advantage of disaggregated data: Insight from forecasting the U.S. economy in a data-rich environment, Ottawa

Pesaran MH, Shin Y, Smith RJ (2001). "Bounds Testing Approaches to the Analysis of Level relationships." J. Appl. Econ., 16(3): 289-326.

Pesaran, M. H. and Pesaran, B. (1997) Working with Microfit 4.0: Interactive Econometric Analysis, Oxford University Press, Oxford.

Pesaran, M. H., Shin, Y., and Smith, R. J. (2004). Bounds Testing Approaches to the Analysis of Long-run Relationships. https://doi.org/10.17863/CAM.5093

Pesaran, M.H., Shin, Y., and Smith, R. (2001). Bounds testing approaches to the analysis of level relationship. Journal of Applied Econometrics 16(3). 174-189.

Peterson J, Farmer R, Lasky M, Mascaro A, Weber A. (2006). The economic effects of recent increases in energy prices. Washington DC, CBO Pub.2825

Ramlan, H. \& Suhaimi, M. S. I. B (2017). The Relationship between Interest Rates and Inflation toward the Economic Growth in Malaysia. Journal of Humanities, Language, Culture and Business, 1(1), 55-63

Ramlan, H. and Suhaimi, M. S. I. B (2017). The Relationship between Interest Rates and Inflation toward the Economic Growth in Malaysia. Journal of Humanities, Language, Culture and Business, 1(1), $55-63$. Retrieved from http://www. icohlcb.com/images/

Reilly T. (2013). Advantages and disadvantages of using monthly, weekly and daily data: Forecasting. Retrieved from: http://www.autobox.com/cms/

Sargent, Thomas J., and Neil Wallace, (1981), "Some Unpleasant Monetarist Arithmetic," Federal Reserve Bank Minneapolis Quarterly Review, Fall, pp. 1-17.

Semuel, Hatane and Nurina, Stephanie. (2015). "Analysis of the Effect of Inflation, Interest Rates, and Exchange Rates on GDP in Indonesia.” Retrieved from: http://globalbizresearch.org/

Tabi H. and Ondoa H. (2011): Inflation, Money and Economic Growth in Cameroon, International Journal of Financial Research, Vol. 2 No. 1

Tang, C.F. and Lean, H.H. (2007) Is the Phillips curve stable for Malaysia? New empirical evidence. Malaysian Journal of Economic Studies, 44(2), pp. 95- 105.

Taylor J.B. (2014). Inflation targeting in emerging markets: The global experience. Stanford.

Totonchi, J. (2011). Macroeconomic Theories of Inflation. International Proceedings of Economics. Development \& Research, 4. 36

Vaish, M.C. 2011. Macroeconomic Theory, 14th ed., Vikas Publishing House PVT LTD, India Wolde-Rufael, Y. (2008), "Budget Deficit, Money and Inflation: The Case of Ethiopia", Journal of Developing Areas, Vol. 42, pp. 183-199. 